\title{
Evaluation of Anti-Cancer Properties of Lichens Using Albino wistar Rats as an Animal Model
}

\author{
Shanmugam Poornima ${ }^{1}$, Ponnusamy Ponmurugan ${ }^{1, ~ *, ~ K h a d e r ~ S y e d ~ Z a m e e r ~ A h m e d ~}{ }^{1}$, \\ Ganesan Ayyappadasan $^{1}$, Fahad Khalid Aldhafiri ${ }^{2}$, Balakrishnan Santhanaraj ${ }^{2}$ \\ ${ }^{1}$ Department of Biotechnology, K. S. Rangasamy College of Technology, Tiruchengode, Namakkal District, Tamil Nadu, India \\ ${ }^{2}$ College of Applied Medical Sciences, Majmaah University, Al Majmaah, The Kingdom of Saudi Arabia
}

\author{
Email address: \\ drponmurugan@gmail.com (P.Ponmurugan) \\ ${ }^{*}$ Corresponding author
}

\section{To cite this article:}

Shanmugam Poornima, Ponnusamy Ponmurugan, Khader Syed Zameer Ahmed, Ganesan Ayyappadasan, Fahad Khalid Aldhafiri, Balakrishnan Santhanaraj. Evaluation of Anti-Cancer Properties of Lichens Using Albino wistar Rats as an Animal Model. Cancer Research Journal. Vol. 4, No. 6, 2016, pp. 84-89. doi: 10.11648/j.crj.20160406.11

Received: October 20,2016; Accepted: November 4, 2016; Published: November 29, 2016

\begin{abstract}
Studies were undertaken to evaluate the efficacy of purified lichen extracts against cancer induced Albino wistar rats as an animal model under in vivo condition. Lichen species were collected from different mean sea level of Yercaud hills of Tamil Nadu, India. Extraction and purification of lichen compounds were done using silica gel column chromatography with TLC analysis. Different fractions were collected from the crude extract and it was subjected to study the potential of anticancerous property. Anticancer activity was confirmed that Parmotrema reticulatum exhibited the highest control over the cervical cancer in cell line model. The compound Benzoic acid, 2, 4 dihydroxy, 6 methyl-methyl ester was identified as a potent molecule from Rocella montagnei. Anticancer effect of $P$. reticulatum and P. hababianum and their compounds were further evaluated to have the effective cancer drug against cervical cancer disease. Cancer cell line induced rats showing a significant reduction tumor proliferation which were treated with bioactive anti-cancer lichen compounds in comparison with the standard drug. Histopathology and hematology studies have been done to examine to confirm the level of tumor growth in the animals and to analyze the blood platelet count in tumors; respectively.
\end{abstract}

Keywords: Cancer, Lichens, Parmotrema Reticulatum, Rocella Montagnei, Animal Model

\section{Introduction}

Cancer is of paramount importance today in terms of third leading cause of cancer-related death worldwide to human beings [1]. It develops because of the progressive accumulation of genetic and epigenetic alterations in human body cells that lead to the transformation of normal colonic epithelium to colon adeno carcinoma. Indeed, consumption of high levels of red meat and fat together with low levels of fruits, vegetables and fibers has been suggested to increase the risk of cancer incidence [2]. Moreover, scientific investigations are making the best efforts to combat this disease, but there is not sure-shot, perfect cure is yet to be brought into world medicine. So alternative solution to western medicine has their own severe side effects and the use of medicinal plant preparations to arrest the insidious nature of the disease [3]. Many herbal plants have been evaluated in clinical studies and currently being investigated phytochemicaly to understand their tumoricidal actions against various cancers [4]. The rich and diverse plant sources of India are likely to provide effective anti-cancer agents. It is of the best approaches in the search for anticancer agents from plant resources is the selection of plants based on ethnomedical leads [5].

It has been reported that there are over 100 different types of cancer in the world, and each is classified by the type of cells that are initially affected. Cancer harms the body when altered cells divide uncontrollably to form lumps or masses of tissue called tumors. Normal cells in the body follow an orderly path of growth, division and death. Programmed cell 
death is called apoptosis and when this process breaks down, cancer begins to form in human body. Cancer is caused by various genetic factors, life style factors such as tobacco use, food diet and physical activity, certain type of infections and the environmental exposes to different types of chemicals and radiation. The cancer prevalence is established to be around 2,500,000 (2.5 million) people with over 800,000 new cases and 5,50,000 deaths occurring each year. More than $70 \%$ of the cases present in advanced stage accounting for poor survival and high mortality. About $6 \%$ of all deaths in India are due to cancers, which contribute to $8 \%$ of global cancer mortality [6]. The current Indian population is around $1,270,272,105$ (1.27 billion) in which the incidence of cancer in India alone is measured by $70-90 \%$ due to disease severity at matured stage [7].

Some of the most important types of cancer include Adrenal cancer, Anal cancer, Bladder cancer, Breast cancer, Colon cancer, Eye cancer, Leukemia cancer, Lung cancer, Liver cancer, Ovarian cancer, Pancreatic cancer, Oral cancer, Skin cancer and Thyroid cancer. Some of the sign and symptoms of cancer are unexplained weight loss, continuous fever, hair loss, skin changes (skin cancer), change in bowel habits or bladder function, unusual bleeding or discharge and nagging cough or hoarseness. There are more than 100 cancer drugs generally used to control the cancer growth. Presently available therapies including surgery, radiation and chemical therapeutic drugs, are still limited for advanced stages of carcinogenesis. Chemoprevention remains an effective and promising additional strategy for controlling the incidence of cancer [8]. The some of the drugs are commonly used such as Abiraterone acetate, Abitrexate, Bicalutamide, Cabazitaxel, Cytarabine, Degarelix, Zelboraf and Vorinostat for the control of cancer [9]. The main objectives of the present study is to collection and identification of various lichen species obtained from Eastern Ghats (Yercaud and Kolli hills) of Tamil Nadu, India and subjected to extract, characterize and purify the bioactive anti-cancerous compounds using various bioassay techniques. Further, it was evaluated the efficacy of bioactive anti-cancerous lichen compounds against cancer induced Albino wistar rats subsequently it was analyzed the hematological, histopathological and biochemical studies of both treated and untreated experimental rats.

\section{Methodology}

\subsection{Collection, Characterization and Identification of Various Lichen Species}

Lichen species were collected from different agroclimatic regions of Yercaud and Kolli hills of Tamil Nadu. The collected lichen species were brought to laboratory in a sterile condition. Then it was subjected to identify by using various colour test $(\mathrm{K}, \mathrm{C}, \mathrm{KC}$ and $\mathrm{PD})$ and morphologically on chemical basis [10]. The chemistry of the individual lichen species were done in different solvent system [11]. The identified lichen species were authenticated and maintained at Herbarium of K. S. Rangasamy College of Technology, Tiruchengode, Tamil Nadu for further uses.

\subsection{Extraction and Characterization of Anticancer Compounds from Lichens}

Based on the available quantity, the lichen species were subjected to sequential extraction of increasing polarity (Hexane, Ethyl acetate and Methanol) to extract bioactive compounds present in it using Soxhalet apparatus. The dried powder was obtained and which was served as a crude extract for performing bioassay guided fractionation [12].

\subsection{Purification of Lichen Extracts Using Column Chromatography}

The dried powder was mixed with silica gel to purify the crude extract in column chromatography. The elution profile was done based on the different ratio of increasing polarity. Eluted sample was collected based on volume and was stored in room temperature. Various fractions of lichen sample was further purified and confirmed using Thin layer chromatography, GC-MS and HPLC analysis. The bioassay of lichen fraction was done on the basis of DPPH analysis which helps to find out the bioactive anticancer compounds from the lichen species [13].

\subsection{Cytotoxicity Assays of Lichen Extracts Against in Vitro Cancer Cell Line}

The four different cancer cell lines were obtained from National Centre for Cell and Science, Pune, India for the present study. The cell lines were sub-cultured and maintained at $\mathrm{CO}_{2}$ Incubator at $37^{\circ} \mathrm{C}$. Then it was subjected to treat with various concentrations of crude extracts as well as various fractions for doing cell toxicity MTT assay. The toxicity of cancer cell lines with our extracts was measured by calculating the inhibitory concentration $\left(\mathrm{IC}_{50}\right)$. Cell count and viability was done using Hemocytometer and trypan blue assay [14].

\subsection{Evaluation of Bioactive Anti-cancer Lichen Compounds Against Cancer Induced Albino Wistar Rats}

Healthy adult Albino Wistar rats weighing around 180-250 gm were maintained at an ambient temperature of $25 \pm 20^{\circ} \mathrm{C}$ and relative humidity of $55-65 \%$ for $12 \pm 1$ hours of light and dark schedule in the Animal House of K. S. R. College of Technology, Tiruchengode, Tamil Nadu. They were fed with commercially available rat chow (Hindustan Lever Ltd., Bangalore) with free access to water [15]. The experimental protocol is approved by the Institutional Animal Ethics Committee (CPCSEA Registration No.: 1826/PO/EReBi/S/15/CPC).

After adaptation of one week the rats were cancer induced with DLA cancer cell lines at Amala cancer research institute, Tirussur, Kerala. The rats developed swelling in the lateral side of its body. After 11 days, cancer fluid was aspirated from the peritoneal cavity of the rats and injected $(1,00,000$ cells / ml) into another group of animals after counting the cells in heamocytometer [16]. Histopathology 
and hematology analysis was done for different organs against control rats [17].

\subsection{Experimental Animal Groups}

Group I: Normal control rats

Group II: Cancer treated control rats received no drugs or lichen compounds

Group III: Cancer treated rats that receive anti-cancer lichen compounds (100 mg/k.g.b.w)

Group IV: Cancer treated rats that receive anti-cancer lichen compounds (200mg/k.g.b.w.)

Group V: Cancer Treated rats that receive standard drug (Vincristine 3mg/k.g.b.w)

\section{Results}

The lichen species were collected from Yercaud hills and were subjected to identify by colour tests as well as presence of isidia, soredia, apothesia, cilia, rhizines and spores. The results were given in the Table 1 for identification and authentication purpose. The result revealed that Parmelliaceae family covering six species were identified and deposited at herbarium of K. S. Rangasamy College of Technology, Tiruchengode, Tamil Nadu for research and voucher specimens. These were further purified for the bioactive anticancerous molecules present in it. Furthermore results indicated that there were more abundance of lichens in the form of foliose lichens than crustose and fruticose. The high genus level of appearance was observed as parmeliod lichen species at Yercaud and Kolli hills which was used for extraction of bioactive anticancer compounds for the present study.

Table 1. List of various lichen species collected from Yercaud and Kolli hills of Tamil Nadu, India.

\begin{tabular}{|c|c|c|}
\hline Family Name & Genus Name & Lichen Name \\
\hline Parmelliaceae & Parmotrema & $\begin{array}{l}\text { 1. Parmotrema reticulatum (Taylor) M. } \\
\text { Choisy } 1952 \\
\text { 2. Parmotrema grayanum (Hue) Hale } \\
\text { 1974 } \\
\text { 3. Parmotrema hababianum (Gyeln.) } \\
\text { Hale } 1974 \\
\text { 4. Parmotrema austrosinense (Zahlbr.) } \\
\text { Hale } 1974 \\
\text { 5. Parmotrema crinitum (Ach.) M. Choisy } \\
\text { 1952 } \\
\text { 6. Parmotrema tinctorum (Despr. ex Nyl.) } \\
\text { Hale } 1974\end{array}$ \\
\hline
\end{tabular}

\subsection{Classification and Distribution Pattern of Lichen Species}

Lichen species were distributed less abundant at 350 Mean Sea Level (MSL) and which increase in increasing with Mean Sea Level in terms of height of the hills. The results showed that very high abundant level of lichen distribution at 1500 MSL near to Shevroy temple. Moreover Crustose and Foliose lichens were equality distributed and contributed to the entire Yercaud hills whereas Fruticose lichen was less diversity.

\subsection{Extraction of Anticancerous Compounds from Lichen Species}

Lichen compounds were extracted using different solvent systems like Hexane, Ethyl acetate and Methanol for separation of anticancerous compounds. The crude methanol extract was subjected to fractionation using column chromatography with silica gel of 60-120 mesh as stationary phase. The two solvent mixtures of hexane $(\mathrm{H})$ with ethyl acetate (EA) and methanol (M) with ethyl acetate (EA) in different ratios were used as mobile phase. In both solvent systems different ration of mixture was used. In the $100 \%$ hexane and 90: 10 (H: EA) no residue was found during the fractionation process in contrast to this all other solvent ratio either residue or pigment and in some mixture the combination of both were found (Fig. 2). All the fractions were subjected to crystallization by autoevaporation process in which only six fractions has formed crystals.

\subsection{Anticancer Activities of Lichen Extracts Against MG 63 Cell Line and SiHa Cell Line Model}

The selected lichen species were subjected to identify the potential of inhibiting the growth of cancer cell by performing MTT assay. The observation revealed that more than $50 \%$ of lichen species were showed the ability of killing the cancer cell population. Thus the screenings of potential as well as fractionation of lichen compounds were done based on the anticancer activity under in vitro model. The result further revealed that $\mathrm{IC}_{50}$ was observed as $100 \mu \mathrm{g} / \mathrm{ml}$ of extract. Anticancer activity of $P$. reticulatum was studied against HeLa cell lines. The result was observed that significant reduction in the confluency with increase in the concentration of lichen extract. Percentage of inhibition was calculated to study the potential of lichen compounds. At a concentration of $50 \mu \mathrm{g} / \mathrm{ml}$ of extract showed the $50 \%$ of inhibition of cell growth. While increasing the concentration upto $300 \mu \mathrm{g} / \mathrm{ml}$ revealed that there is no viable cell in the sample.

\subsection{Evaluation of Lichen Rocella Montagnei Extracts Against Cancer Induced Rats Model}

The tumor induction had been identified by the bulk appearance of the rats at the peritoneal cavity. The animal has been sacrificed at $13^{\text {th }}$ day and the peritoneal cancer fluid had been aspired from the animal and injected into another animal marked as dorsal female. The cancer fluid was also injected into another animal with no marking, at the subcutaneous (limbs) for solid tumor induction. The new set of animals also showed bulk appearance in their body. After the development of solid tumor, the arts were treated with lichen extracts on cancer induced rats model with the concentration of $100 \mathrm{mg} / \mathrm{k}$.g.b.w and $200 \mathrm{mg} / \mathrm{k}$.g.b.w.

There is a significant variation in haemoglobuline, platelet counts and red, white blood cells in both treated and untreated rats (Fig. 5). The results showed that tumor size 
and volume has been reduced in the significant level of treated rats groups. Treatments given for DLS solid tumor with lichens were most effective compared to standard drug Vincristine. After the treatments the histopathology analysis were done for both treated and untreated organs like kidney, lungs and liver. The necrosis and development of individual cells were analyzed using $\mathrm{H} \& \mathrm{E}$ stain. The slide was observed in the light microscope which showed much significant of reduction of cancer cell populations.
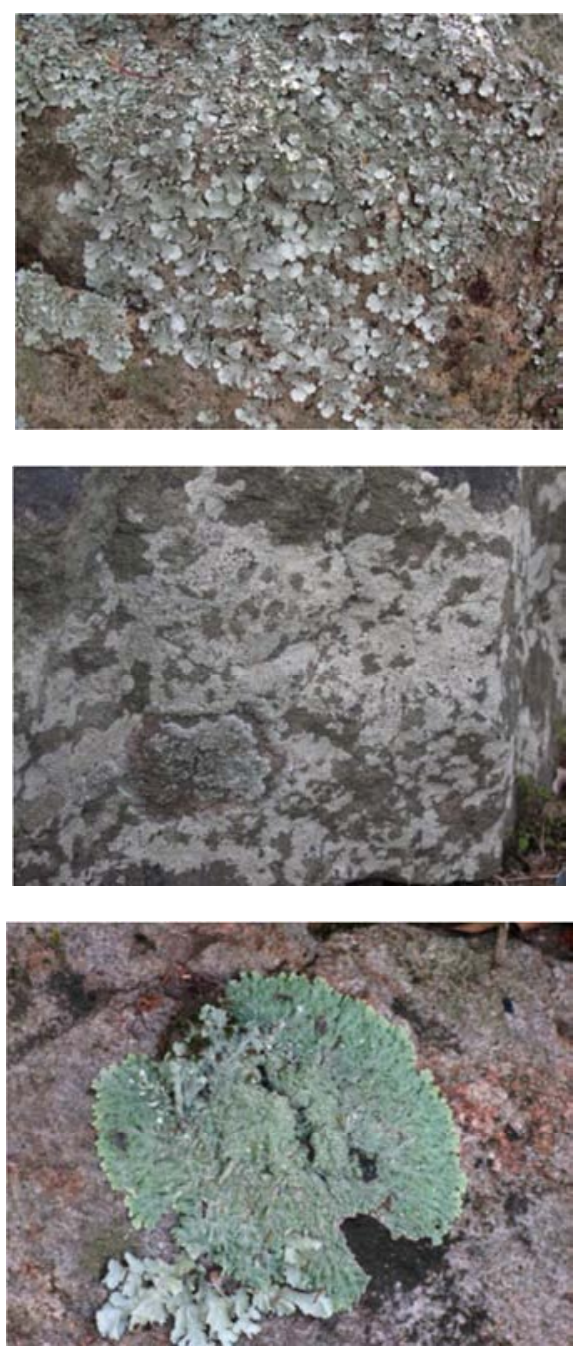

Fig. 1. Collected lichen species at Yercaud hills of Tamil Nadu, India.

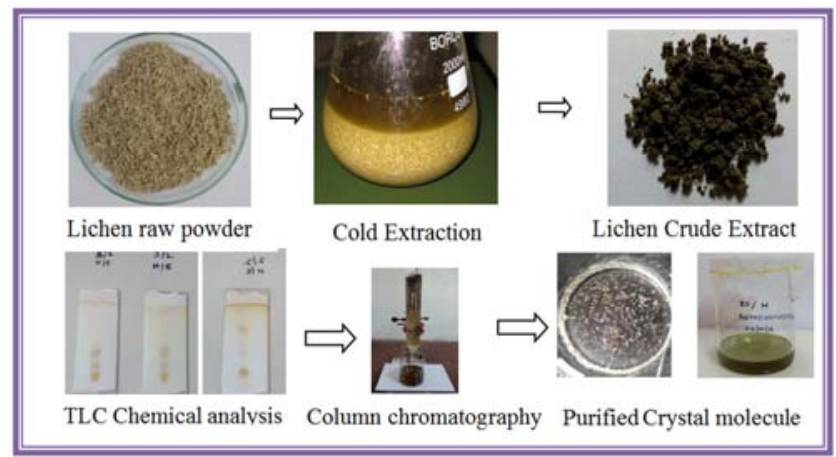

Fig. 2. Extraction and purification of anti-cancerous compounds from lichens.
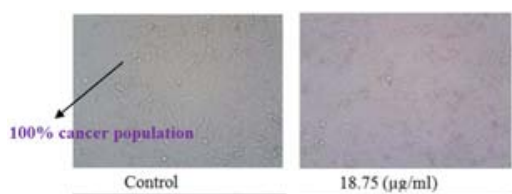

$18.75(\mu \mathrm{g} / \mathrm{ml})$
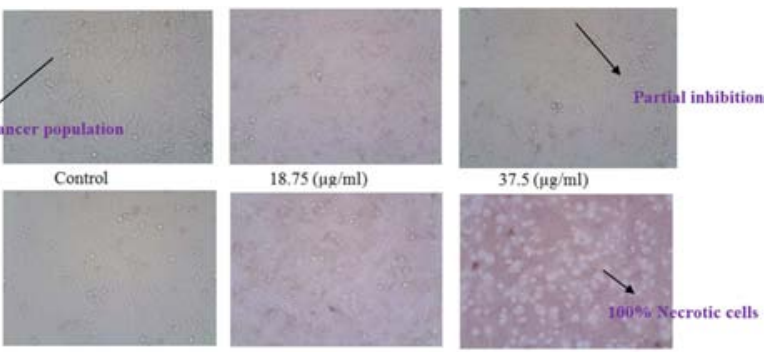

75 ( $\mathrm{\mu g} / \mathrm{ml})$

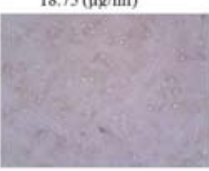

$150(\mu \mathrm{g} / \mathrm{ml})$

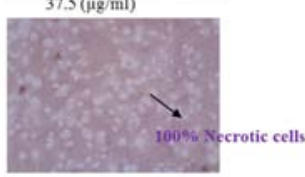

$300(\mu g / m l)$
Fig. 3. Various concentration of lichen extract (Parmotrema hababianum) against MG63 cell line.

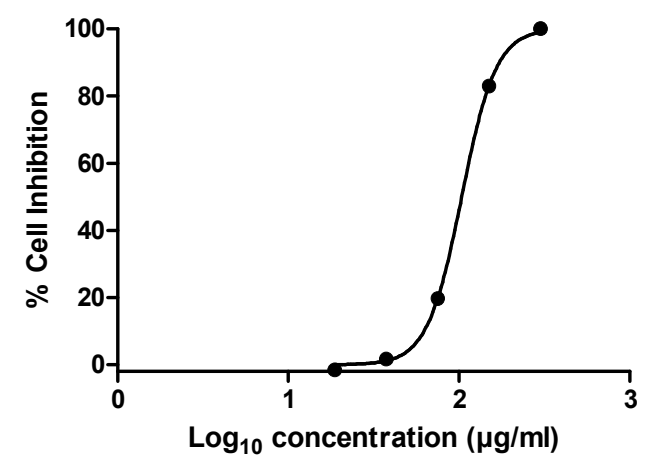

Fig. 4. Study of cancer cell inhibition at different lichen concentrations.
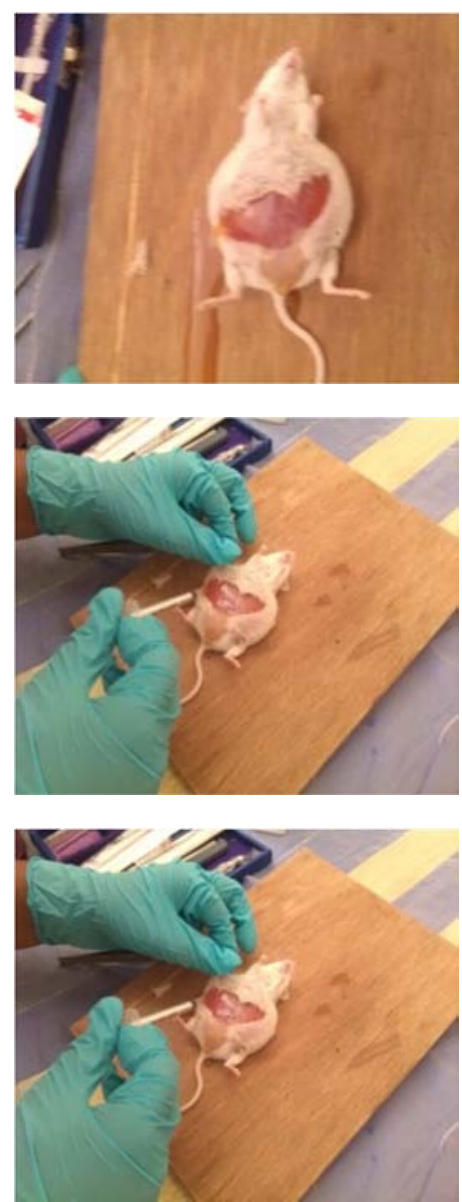

Fig. 5. Maintenance of cancer induced rats for different experimental groups. 


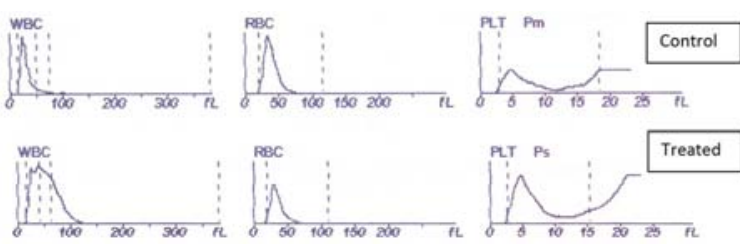

Fig. 6. Hematological analysis of cancer induced and control rats.

\subsection{Histopathology Analysis of Control and Treated Rats Model}

Different organs of treated as well as untreated tissue samples were analyzed for Heamotoxylin and Eosin (HE) stain to assess the tissue damage. Tissue damage was measured in the untreated rats model. The result revealed that tissue was damaged in highest level in the DLS induced rats model. Whereas treated with lichen showed the significant level of reduction in tissue damage which helps to formation of new cells.

\section{Discussion}

Anticancer activity of selected $R$. montagnei exhibited in moderate level of cancer cell population which may be the presence of lichen bioactive substances present in it. The present lichen extract showed better a significant growth inhibition against MG63 cell lines. Similar result was also obtained for anticancer activity of against various cell lines such as FemX (melanoma) and human colon carcinoma cell lines in cytotoxicity assays [18]. The $\mathrm{IC}_{50}$ value of MG63 cell line in lichen $R$. montagnei was obtained as $100 \mu \mathrm{g} / \mathrm{ml}$ in contrast to that Hypogymnia physodes showed very less $\mathrm{IC}_{50}$ in the range of 12.72 to $24.63 \mu \mathrm{g} / \mathrm{ml}$. Anticancer potential of three Umbilicaria lichen species and revealed that IC ${ }_{50}$ in the range of 28.45 to $97.82 \mu \mathrm{g} / \mathrm{ml}$. It has stated that lichen compounds showed better anticancer property against both in vitro and in vivo methods [19].

It has been described that around 17 lichen species were screened in which lichen compounds obtained from Flavocetraria cucullata showed a remarkable anticancer activity in apoptosis process [20]. The similar trend was also observed in $R$. montagnei lichens in apoptosis by the G2 Phase on cell cycle. Usnic acid showed better anticancer activity in mouse model. The anticancer activity of $R$. montagnei might be the presence of usnic acid and other lichen bioactive substituents. The result of cell proliferation and migration was suppressed and represented in MG63 cell lines in which usnic acid at very less dosage of angiogenic power in xenografted tumor based mice model which also described that endothelial cell proliferation, migration and tubulin formation in cancer cell. The mechanism of cancer cell reduction might be role of inhibition breast cancer cell population and suppress of VEGFR2 mediated AKT and ERK1/2 signaling pathway [21].

Hematological parameters were also revealed that tremendous variation in blood cells which also in line with the report of Monica et al. [22] that in vitro and in vivo evaluations of antineoplastic potential of barbatic acid which also explained in detail about the mechanism of apoptosis in cancer cell population. Further, the purified compounds of $R$. montagnei will also evaluated in both in vitro and in vivo conditions against mouse cancer cell line model.

\section{Conclusion}

The present study revealed that the bioactive compounds obtained from Parmotrema reticulatum, P. hababianum and Rocella montagnei exhibited a strong anti-cancerous property which confirmed through cancer cell-line studies and animal model experiments. There was a significant reduction in cancer cell proliferation due to action of lichen bioactive compounds which in turn reflected in cancer induced Albino Wistar rats.

\section{References}

[1] WHO, (2014). Global Status Report on Road Safety: Time for Action. World Health Organization, Geneva, ISBN: 978-92-4156384-0.

[2] Kim, M., Murakami, A., Miyamoto, S., Tanaka, T. \& Ohigashi, H. (2010). The modifying effects of green tea polyphenols on acute colitis and inflammation-associated colon carcinogenesis in male ICR mice. Biofactors, 36, 43-51.

[3] Gordon, M. C. \& Newman, D. J. (2001). Natural product drug discovery in the next millennium. Pharmacy and Biology, 39, $8-17$.

[4] Premalatha, B. \& Rajgopal, G. (2005). Cancer-an ayurvedic perspective. Pharmacological Research, 51, 19-30.

[5] Cordeiro, C. C., Chen, J. B., Wang, S. L. \& Elix, J. A. (2004). Culture studies and secondary compounds of six Ramalina species. Mycological Research, 108, 489-97.

[6] Deepa, P., Murugesh, S. \& Arivukkarasu, R. (2014). HPTLC analysis of Dolichandrone atrovirens (Sprague) plant bark. World Journal of Pharmaceutical Research, 3, 10191029.

[7] Kavimani, S., Saminathan, K. \& Senthil Kumar, R. (2014). Antioxidant and free radical scavenging activities of Dolichandrone atrovirens using various in vitro assay models. International Journal of Phytopharmacology, 5, 293-300.

[8] Guruswamy, S. \& Rao, C. V. (2008). Multi-target approaches in colon cancer chemoprevention based on systems biology of tumor cell-signaling. Gene Regulation and System Biology, 2, 163-176.

[9] Spiridon, K. E. (2006). Terrestrial plant-derived anticancer agents and plants used in anticancer research. Critical Review of Plant Science 25, 79-113.

[10] Walker, F. J. \& James, P. W. (1980). A revised guide to microchemical techniques for the identification of lichen substances. Bulletin British Lichenological Society, 46, 13-29.

[11] Culberson, C. F. (1972). Improved conditions and new data for the identification of lichen products by a standardized thinlayer chromatographic method. Journal of Chromatography, $72,113-125$. 
[12] Yoshimura, I., Kurokawa, T., Kinoshita, Y., Yamamoto, Y. \& Miyawaki, H. (1994). Lichen substances in cultured lichens. Journal of Hattori. Botany Laboratory, 76, 249-261.

[13] Sun, Y., Zhou, X., Liu, J., Bau, K., Zhang, G., Tu, G., Kieser, T. \& Deng, Z. (2002). Streptomyces nanchangensis, a producer of the insecticidal, polyethane antbiotic nanchangmycin and antioarasitic macrolide meilingmycin, contains multiple polyketide gene clusters. Microbiology, 148, 361-371.

[14] Mosmann, T. (1983). Rapid colorimetric assay for cellular growth and survival: application to proliferation and cytotoxicity assays. Journal of Immunological Methods, 65, $55-63$.

[15] Saravanan, G. \& Ponmurugan, P. (2013). Animal Studies: Experimental Procedures. Oxford Publishers, UK.

[16] Natarajan, P. \& Arunpandian, R. (2015). Evaluation of anticancer activity Dolichandrone atrovirens in experimental induced animal model. Indo American Journal of Pharmacy Research, 5, 07-09.

[17] Kumar, K. B. H. \& Kuttan, R. (2005). Chemoprotective activity of an extractor Phyllanthus amarus against cyclo phosphamide induced toxicity in mice. Phytomedicine, 12, 494-500.
[18] Rankovic, B., Kosanic, M., Stanojkovic, T., Vasiljevic, P. \& Manojlovic, N. (2012). Biological activities of Toninia candida and Usnea barbata together with their norstictic acid and usnic acid constituents. International Journal of Molecular Science, 13, 14707-14722.

[19] Kosanic, M, Rankovic, B. \& Stanojkovic, T. (2012). Antioxidant, antimicrobial and anticancer activity of 3 Umbilicaria species. Journal of Food Science, 77, 20-25.

[20] Thanh, T., Somy, Y., Ho-Bin, L., Soonok, O., Min-Hye, J., Jong-Jin, K., Sung-Tae, Y., Florin, C., Cheol, M., Kwang, Y. L., Kyung, K., Jae-Seoun, H. \& Hangun, K. (2014). Cancer effects on human cancer cells through the induction of apoptosis and suppression of tumorigenic potentials. PLoS One, 9 (10), 121-26.

[21] Song, Y, Dai, F, Zhai, D, Dong Y, \& Zhang, J. (2012). Usnic acid inhibits breast tumor angiogenesis and growth by suppressing VEGFR2 - mediated AKT and ERK1/2 signaling pathways. Angiogenesis, 15, 421-432.

[22] Monica, C., Tamiris, A., Thiago, D., Marinaldo, P., Noemia, P., Teresinha, G., Francisco, C., Aguiar, J., Emerson, P., Eugenia, C. P. \& Nicacio, H. (2016). In vitro and in vivo antineoplastic activity of barbatic acid. International Medical Society, 9 (63), 21-25. 